\title{
研究課題別事後評価結果
}

1. 研究課題名：半導体量子構造の探索とテラヘルツ波計測技術開拓

2. 研究代表者名及び主たる研究参加者名 (研究機関名・職名は研究参加期間終了時点):

研究代表者

小宮山 進（東京大学大学院総合文化研究科 教授）

主たる共同研究者

平川 一彦（東京大学生産技術研究所 教授）（平成 18 年 10 月～)

生嶋 健司（東京農工大学工学研究科 准教授）（平成 20 年 4 月～)

AN Zhenghua (Fudan University, Institute of Advanced Materials 准教授)

(平成 20 年 10 月～)

\section{3. 研究実施概要}

本研究では, 超高感度でかつ簡便に使用でき, 広範な応用に適する赤外・テラヘルツ $(\mathrm{THz})$ 波検出器 を開拓することを第一の目標とし, 開発した検出器を用いて超高感度かつ超高分解能のパッシブ(対象物 質以外に光源を用いない) $\mathrm{THz}$ 近接場顕微鏡を開拓することを第二の目標とした. さらに最終目標として， 開発された装置の特徵を生かした物質現象の観測を掲げた。

(1)テラヘルツ波検出器の開発

高純度の GaAs/AlGaAs 2重量子井戸結晶を利用して, 増幅作用を内包する新たな機構の電荷敏感 型赤外検出器 (CSIP: Charge Sensitive Infrared Phototransistor)を構築した. 量子井戸の結晶成長 について、自主開発を行うとともに外部委託もあわせて非常に高品質の基板を得ることができ、従来型の検 知器に比較して桁違いに感度の高い検知器を実現した。さらにリセット信号の導入によりダイナミックレンジ の大幅な改善に成功した.

さらに動作方法・入射光と電子との結合方法・素子構造，および励起光の入射方法の最適化を進めて 14 16 $16 \mathrm{~m}$ の波長領域において感度を約 20 倍改善した. このようにして完成した CSIP 検知器は, 液体へリ ウム温度以上 $(<23 \mathrm{~K})$ で動作し, 従来の検出器に比べて 1000 倍程度の感度を有する. 信号電流が大きい ために, 検出器信号の取り扱いが極めて簡便, かつ入射光強度のダイナミックレンジが極めて広い等, 応用 のために多くの利点を有する. 研究では, さらにいくつかの方法によって波長帯域の拡大を試み, 新たに考 案した横脱出方式の採用により $45 \mu \mathrm{m}$ においても実用的な感度を得た。

CSIP は信号電流が入射光の時間積分で出力される点で CMOS センサーの動作に類似していることか らアレー化に適している. 本研究ではアレー化の可能性を実証するため, 2 層の配線を実現するリソグラフ 技術により, 20x20 画素のアレー素子(波長 14 15 $\mu \mathrm{m}$ )を作成し, 動作確認を行った. 歩留まりに問題はあ るものの, 原理実証には成功した.

(2) パッシブ THz顕微鏡の開発

開発した超高感度 CSIP 検出器 (12 16 $\mu \mathrm{m}$ ) を用いた共焦点顕微鏡と AFM (原子間力顕微鏡) 技術を組 み合わせることにより, 外部光源による照射をいっさい行わず, 試料自体が表面近傍に発する極めて微弱な $\mathrm{THz}$ 光のパッシブ計測が可能な散乱型の高感度高分解能 $\mathrm{THz}$ 近接場顕微鏡 (s-SNOM; scattering-type Scanning Near-Field Optical Microscope)を世界で初めて構築した。

(3) 物質現象の観測への応用

開発したパッシブ THz顕微鏡を用いて常温の試料自身が発する微弱な $\mathrm{THz}$ 近接場を, はるかに強い背 景輻射から分離観測することに成功した.この顕微鏡を用いて各種の金属および誘電体およびそこに形成 された各種のパターンを観察し, 有限温度の試料が表面に強く局在した強力な熱励起のエバネセント波を 普遍的に有寸ることを見出した.このエバネセント波は, 伝播波であるプランク輻射と異なるだけでなく, 物質 
表面の固有振動モードのプラズモンやフォハンよる表面ポラリトンとも異なる. このエバネッセント波は電子 またはイオンの熱運動に伴う電荷摇らぎに起因し, 荷電粒子の局所密度の摇らぎの空間スケールより短い 距離まで表面に接近することで初めて検出することができる.この現象は理論で潜在的に予測されていたが， 従来検出の困難さから実験的に観測されなかったものである.

\section{4. 事後評価結果}

4-1. 研究の達成状況及び得られた研究成果 (論文・口頭発表等の外部発表, 特許の取得状況等を含む)

(1) 原著論文発表(国際誌 32 件、その他の著作物・総説、書籍 7 件

(2) 学会招待講演(国内会議 8 件、国際会議 8 件)

(3) 学会口頭発表(国内会議 17 件、国際会議 14 件)ポスター発表(国際会議 8 件)

(4) 国内特許出願 2 件、海外特許出願 2 件

本研究の根幹となるのは, $\mathrm{THz}$ ·赤外検知素子の開発である. 従来, 赤外〜遠赤外領域では, 感度のよい素 子がなく, 開発も困難とされていたが, 独自のアイディアにより $14 \mu \mathrm{m}$ 帯で従来の 1000 倍といらきわめて高い感 度を持つ素子の開発に成功した. しかもダイナミックレンジも大きく, 構造も比較的単純で, アレー化も可能であ ることから広い応用が考えられる.さらに, プロジェクト最終年度に横脱出方式といら新たな方式で $45 \mu \mathrm{m}$ 帯での 検知器の作成に成功し, 感度のさらなる長波長領域への拡大に道を開いた. これらの成果は, $\mathrm{THz} \cdot$ 赤外領域 での基盤的技術なので, その意義は大きい.

さらに, この素子を用いた近接場顕微鏡を構築し, $60 \mathrm{~nm}$ といら高い空間分解能を達成した. これにより, 室温 の物体が発する電磁波について詳細な研究が進み, 金属内部の電子の熱的な摇らぎに起因する強大なエバ ネッセント波が金属表面近傍に存在することを発見した.これは固体において普遍的な現象であると見られ，吸 着分子や触媒反応に対寸る効果など未知の現象の発見につながる可能性がある.

以上のように, 本研究では機器開発と物理現象解明の両面で非常に独創性の高い研究成果が上がっており, 本領域の目標が十分に達成されたといえる.

以上の成果は, 原著論文発表 （国際(欧文)誌 32 件), 招待講演 (国内会議8件, 国際会議 8件), 口 頭発表（国内会議 17 件, 国際会議 14 件)などで学術的成果として発表されており, 国際的にも高い評価 を受けている.

また, 検知器の改良に伴う重要なアイディア(分割電極, 光結合機構)については, 国内出願（2 件）, 赤外 光検出器本体については, 米国, 欧州 (ドイツ・英国)で海外出願（2 件)を申請しており, 測定機器開発といら本 領域の戦略目標に大きく貢献している.

\section{4-2. 研究成果の科学技術や社会へのインパクト, 戦略目標への貢献}

今回開発された CSIP は非常にユニークな特徵を持つ優れた検出器であり, 高感度, 広ダイナミックレンジの みならず, その使い勝手の良さから今後さまざまな目的に応用されると考えられる. 本格的なアレー化が進めば, 応用範囲はさらに大きく広がるだろう. なかでも高感度性が最大限に発揮されるのは, 天文への応用と思われる. 人工衛星への搭載がもし実現すれば, 大きな契機になるだろう. 日本の次世代赤外線天文衛星として SPICA (Space Infrared Telescope for Cosmology and Astrophysics)が 2018 年の打ち上げを目指しているので, ここに採用されることが一つの目標になろう.

今回発見された, 金属(および誘電体)の極めて強い熱励起エバネセント波は, 基本的には物理学的観点か らその価值が評価されるべき成果であるが, 実用的観点からは, 探針を用いたナノメートル分解能のサーモメトリ (実証済み)や, ナノメートル領域の輻射冷却や輻射加熱の可能性を示唆するものである. また, 物質表面に普 遍的に存在するエバネセント波は物質の表面反応, 触媒作用, 分子の化学吸着等の研究に資する, 新たな計 測手法として多方面への応用と展開が期待でき, 基礎的物性, 物理化学研究に役立つ可能性も高い. 寸でに テラヘルツ近接場顕微鏡の一部商品化も検討が始まっており, 波及効果への期待感が持てる.

4-3. 総合的評価 
本研究は, 新方式の赤外・テラヘルツ波の計測技術を開拓したものであり, 特に $14 \mu \mathrm{m}$ 帯で従来の検知器の 1000倍の感度を実現したこと, 横脱出方式により天文観測で要望の強かった $45 \mu \mathrm{m}$ 帯でも同等の感度を実現し， さらなる長波長化の可能性も示したことは特筆に価する. さらに, 超高感度といら特性を生かした物質現象の研 究として, 固体表面近傍における強力な電磁場摇らぎが存在することを発見した.いずれも類似研究が存在し ない, 非常にオリジナリティーの高い仕事であり, クレストの研究成果として高く評価できる. 日本発の新技術とし て発展, 定着させるためには今後も何らかの方法で実用化, 商品化の研究が続けられることが望まれる. 特にア レー化は大学の研究室レベルでは困難な仕事であるが, 企業の協力があれば必ず実現できる技術なので, 企 業の参入に期待する. 